\title{
PENGARUH INFLASI, SUKU BUNGA BANK INDONESIA (BI), DAN NILAI TUKAR RUPIAH/US\$ TERHADAP PEREKONOMIAN INDONESIA
}

\author{
Oleh: \\ Miralda Indiarti \\ miralda89@yahoo.com \\ Sekolah Tinggi Ilmu Ekonomi IPWI Jakarta
}

\begin{abstract}
ABSTRAK
Tujuan penelitian ini adalah untuk membuktikan adanya pengaruh variabel bebas pertama yaitu inflasi, suku bunga BI variabel bebas kedua, dan variabel bebas ketiga yaitu nilai tukar Rupiah/US\$ terhadap variabel terikat yaitu Produk Domestik Bruto $(P D B)$ sebagai salah satu indikator perekonomian Indonesia pada periode Nopember 2015 - April 2018. Dengan bantuan program SPSS versi 24 didapat hasil penelitian bahwa determinasi koefisien nilai $R$ sebesar 0,905 dan nilai $R$ Square sebesar 0,819 atau $81,9 \%$. Hal ini dapat dinyatakan dengan hasil analisa secara bersama-sama variabel independen inflasi (X1), suku bunga BI (X2), dan nilai tukar Rupiah/US\$ (X3) terhadap variabel dependen Produk Domestik Bruto (PDB) $(Y)$ memiliki nilai positif dan tingkat persentase pengaruhnya sangat tinggi yaitu sebesar $81,9 \%$ dan sisanya sebesar 19,1\% disebabkan oleh faktor-faktor lain. Berdasarkan pada hasil uji ANOVA didapat nilai ratio - F sebesar 39,088. Selanjutnya dapat dikatakan variabel inflasi (X1), suku bunga BI (X2), dan nilai tukar Rp/US\$ (X3) secara bersama-sama berpengaruh dengan variabel $P D B(Y)$.
\end{abstract}

Kata Kunci: Inflasi, Nilai Tukar Rupiah/US\$, Suku Bunga Deposito, Produk Domestik Bruto

\section{PENDAHULUAN}

Memasuki era digital membuat batas-batas negara menjadi bias, dimana tidak ada lagi penghalang bagi semua negara di dunia untuk saling berkomunikasi dan bertransaksi bisnis hanya dalam hitungan menit pada jarak yang sangat jauh sekalipun. Akibatnya apabila terjadi krisis ekonomi di suatu negara adidaya (AS) maupun negaranegara Eropa maka negara-negara lain termasuk negara-negara berkembang akan terkena imbasnya, dimana timbulnya saling ketergantugan antar negara di dunia.

Melansir CNN Money, Selasa (31/3/2015) (http://money.cnn.com), memasuki tiga bulan pertama di 2015, ekonomi negara Amerika Serikat mulai menunjukkan tanda-tanda pelemahannya. Para ekonom di AS menyimpulkan, goyahnya ekonomi AS ini disebabkan oleh dua faktor. Pertama, upah buruh yang naik tidak signifikan dan melambatnya ekonomi negara di dunia yang secara langsung memberi tekanan pada ekonomi AS. Pada Desember 2015 Bank Sentral Amerika Serikat (Federal Reserve) menaikkan suku bunganya untuk pertama kalinya dalam satu dekade (disusul kenaikan suku bunga pada Desember 2016).

Namun, karena inflasi Indonesia dan defisit transaksi berjalan membaik ke tingkat yang aman, sedangkan rupiah mulai stabil terhadap dolar AS dari akhir 2015, Bank Indonesia akhirnya bisa melonggarkan kebijakan moneternya. Sepanjang 2016 bank sentral Indonesia mampu menurunkan suku bunga secara drastis dari level 7,75 persen pada awal 2016 menjadi 4,75 persen pada akhir 2016 (ini juga termasuk perubahan dari BI rate ke BI 
7-day Reverse Repo Rate sebagai alat benchmark bank sentral), maka memungkinkan aktivitas ekonomi yang lebih cepat. Namun, per awal 2018 pertumbuhan kredit tetap lemah di Indonesia (Indonesia Investment, $7 \mathrm{Mei}$ 2018).

Nilai tukar rupiah kembali terpuruk. Rupiah tercatat diperdagangkan di atas 14.000 per USD untuk pertama kalinya sejak Desember 2015. Ini dipicu kekhawatiran jika pertumbuhan ekonomi yang di luar target, dapat membatasi opsi bank sentral untuk mempertahankan mata uang ini. Mengutip laman Bloomberg, Senin (7/5/2018), rupiah anjlok 0,5 persen menjadi 14.003 per USD, sebelum diperdagangkan pada 13.999 pukul 4:55. Dalam 3 bulan terakhir, mata uang Garuda telah melemah 3,2 persen. Ini membuatnya menjadi pemain terburuk kedua di Asia setelah rupee India, mengutip data Bloomberg.

Pertumbuhan ekonomi di Indonesia diukur dengan pertumbuhan Produk Domestik Bruto (PDB). Pertumbuhan PDB Indonesia diperkirakan segera kembali ke tingkat di atas 6 persen (y/y). Bahkan baru-baru ini, lembagalembaga internasional seperti IMF dan Bank Dunia masih tetap terlalu positif tentang laju pertumbuhan ekonomi Indonesia. Misalnya, Bank Dunia dan IMF memprediksi bahwa ekonomi Indonesia bisa tumbuh 5.3 persen $(\mathrm{y} / \mathrm{y})$ pada tahun 2017, sedangkan realisasi pertumbuhan pada tahun itu hanya berada di 5,07 persen (y/y) (Indonesia Investment, 7 Mei 2018).

Proyeksi pertumbuhan ekonomi Indonesia tetap "positif" dalam arti bahwa sebagian besar - jika tidak semua - lembaga internasional dan domestik yang relevan meramalkan percepatan pertumbuhan ekonomi bagi Indonesia pada tahun-tahun mendatang.

\section{TUJUAN PENELITIAN}

Tujuan penelitian ini adalah untuk membuktikan apakah variabel bebas pertama $\left(\mathrm{X}_{1}\right)$ yaitu inflasi, suku bunga $\mathrm{BI}$ variabel bebas kedua $\left(\mathrm{X}_{2}\right)$, dan variabel bebas ketiga yaitu nilai tukar
Rupiah/US\$ $\left(\mathrm{X}_{3}\right)$ akan mempengaruhi variabel terikat (Y) yaitu Produk Domestik Bruto (PDB) sebagai indikator Perekonomian Indonesia periode Nopember 2015-April 2018.

\section{TELAAH LITERATUR DAN PENGEMBANGAN PROPOSISI/HIPOTESIS Inflasi (Kenaikan Harga)}

Secara sederhana inflasi diartikan sebagai kenaikan harga secara umum dan terus menerus dalam jangka waktu tertentu. Kenaikan harga dari satu atau dua barang saja tidak dapat disebut inflasi kecuali bila kenaikan itu meluas (atau mengakibatkan kenaikan harga) pada barang lainnya. Kebalikan dari inflasi disebut deflasi.

Indikator yang sering digunakan untuk mengukur tingkat inflasi adalah Indeks Harga Konsumen (IHK). Perubahan IHK dari waktu ke waktu menunjukkan pergerakan harga dari paket barang dan jasa yang dikonsumsi masyarakat. Penentuan barang dan jasa dalam keranjang IHK dilakukan atas dasar Survei Biaya Hidup (SBH) yang dilaksanakan oleh Badan Pusat Statistik (BPS). Kemudian, BPS akan memonitor perkembangan harga dari barang dan jasa tersebut secara bulanan di beberapa kota, di pasar tradisional dan modern terhadap beberapa jenis barang/jasa di setiap kota.

Berdasarkan tingkat kelajuan kenaikan harga yang berlaku, inflasi dapat dibedakan kepada tiga golongan :

1. Inflasi merayap, proses kenaikan harga-harga barang yang lambat jalannya. Dimana kenaikan hargaharga yang tingkatnya tidak melebihi dua atau tiga persen setahun, contohnya Malaysia dan Singapura.

2. Hiperinflasi, proses kenaikan hargaharga yang sangat cepat, yang menyebabkan tingkat harga menjadi dua atau beberapa kali lipat dalam masa yang singkat, contohnya perekonomian Indonesia pada tahun 1965 tingkat inflasi 500\%.

3. Moderate Inflation, negara-negara berkembang adakalanya tingkat inflasi tidak mudah dikendalikan, 
tidak mampu menurunkan inflasi pada tingkat yang sangat rendah. Secara rata-rata di sebagian negara tingkat inflasi mencapai 5-10\% digolongkan sebagai inflasi sederhana.

Kenaikan harga menyebabkan barang-barang negara itu tidak dapat bersaing di pasaran internasional. Maka ekspor akan menurun. Sebaliknya, harga-harga produksi dalam negeri yang semakin tinggi sebagai akibat inflasi menyebabkan barang-barang impor menjadi relative murah. Ekspor yang menurun dan diikuti impor yang bertambah menyebabkan ketidakseimbangan dalam aliran mata uang asing, kedudukan neraca pembayaran akan memburuk.

1. Inflasi akan menurunkan pendapatan rill orang-orang yang berpendapatan tetap. Pada umunya kenaikan upah tidaklah secepat kenaikan harga-harga.

2. Inflasi akan mengurangi nilai kekayaan yang berbentuk uang. Sebagian kekayaan masyarakat disimpan dalam bentuk uang, nilai riilnya akan menurun apabila inflasi berlaku.

3. Memperburuk pembagian kekayaan. Inflasi menyebabkan pembagian pendapatan di antara golongan berpendapatan tetap dengan pemilik-pemilik harta tetap dan penjual/pedagang akan menjadi semakin tidak merata (Sukirno, 2003:333-339).

\section{Suku Bunga BI}

BI Rate adalah suku bunga kebijakan yang mencerminkan sikap atau stance kebijakan moneter yang ditetapkan oleh Bank Indonesia dan diumumkan kepada publik. BI Rate diumumkan oleh Dewan Gubernur Bank Indonesia setiap Rapat Dewan Gubernur bulanan dan diimplementasikan pada operasi moneter yang dilakukan Bank Indonesia melalui pengelolaan likuiditas (liquidity management) di pasar uang untuk mencapai sasaran operasional kebijakan moneter. Sasaran operasional kebijakan moneter dicerminkan pada perkembangan suku bunga Pasar Uang
Antar Bank Overnight (PUAB O/N). Pergerakan di suku bunga PUAB ini diharapkan akan diikuti oleh perkembangan di suku bunga deposito, dan pada gilirannya suku bunga kredit perbankan.

Respon kebijakan moneter dinyatakan dalam perubahan BI Rate secara konsisten dan bertahap dalam kelipatan 25 basis poin (bps). Dalam kondisi untuk menunjukkan intensi Bank Indonesia yang lebih besar terhadap pencapaian sasaran inflasi, maka perubahan BI Rate dapat dilakukan lebih dari 25 bps dalam kelipatan 25 bps. Dengan mempertimbangkan pula faktor-faktor lain dalam perekonomian, Bank Indonesia pada umumnya akan menaikkan BI Rate apabila inflasi ke depan diperkirakan melampaui sasaran yang telah ditetapkan dan sebaliknya.

Bank Indonesia melakukan penguatan kerangka operasi moneter dengan memperkenalkan suku bunga acuan atau suku bunga kebijakan baru yaitu BI 7-Day Repo Rate, yang akan berlaku efektif sejak 19 Agustus 2016. Selain BI Rate yang digunakan saat ini, perkenalan suku bunga kebijakan yang baru ini tidak mengubah stance kebijakan moneter yang sedang diterapkan. Dengan penggunaan instrumen BI 7-day (Reverse) Repo Rate sebagai suku bunga kebijakan baru, terdapat tiga dampak utama yang diharapkan. Pertama, menguatnya sinyal kebijakan moneter dengan suku bunga (Reverse) Repo Rate 7 hari sebagai acuan utama di pasar keuangan. Kedua, meningkatnya efektivitas transmisi kebijakan moneter melalui pengaruhnya pada pergerakan suku bunga pasar uang dan suku bunga perbankan. Ketiga, terbentuknya pasar keuangan yang lebih dalam, khususnya transaksi dan pembentukan struktur suku bunga di pasar uang antarbank (PUAB) untuk tenor 3-12 bulan.

\section{Nilai Tukar/ Kurs}

Kurs feferensi: Jakarta Interbank Spot Dollar Rate (JISDOR). JISDOR merupakan harga spot USD/IDR, yang disusun berdasarkan kurs transaksi 
USD/IDR terhadap rupiah antar bank di pasar valuta asing Indonesia, melalui Sistem Monitoring Transaksi Valuta Asing Terhadap Rupiah (SISMONTAVAR) di Bank Indonesia secara real time.

JISDOR dimaksudkan untuk memberikan referensi harga pasar yang representatif untuk transaksi spot USD/IDR pasar valuta asing Indonesia. JISDOR mulai diterbitkan sejak 20 Mei 2013.

Sejalan dengan tujuan kebijakan nilai tukar, maka dikenal berbagai jenis sistem nilai tukar yang digunakan oleh suatu negara:

1. Nilai tukar mengambang (floating exchange rate system), dalam sistem nilai tukar mengambang, nilai tukar mata uang suatu negara sematamata ditentukan dari adanya permintaan dan penawaran mata uangnya dalam bursa pertukaran mata uang internasional.

2. Nilai tukar tetap (fixed exchange rate system), pemerintah dapat mempertahankan suatu kebijakan yang menjaga agar nilai mata uangnya tetap pada tingkat yang stabil dengan mengintervensi di pasar devisa.

3. Nilai tukar terkendali (managed floating exchange rate system), sistem ini berlaku pada situasi dimana nilai tukar ditentukan berdasarkan permintaan dan penawaran, tetapi bank sentral dari waktu ke waktu ikut campur tangan guna menstabilkan nilainya.

Penghapusan batas intervensi rupiah pada bulan Agustus 1997 itu, sesaat setelah krisis keuangan Asia tersebut muncul, menandakan telah terjadi suatu perubahan besar terhadap sistem penentuan kurs yang dianut oleh BI selama era orde baru. Yakni dari sistem bebas terkendali ke sistem bebas (yakni kurs rupiah ditentukan oleh kekuatan pasar permintaan dan penawaran valuta asing (Tambunan, 2016:177-178).

Menurut Sukirno (2003:362) terdapat lima faktor-faktor yang mempengaruhi kurs yaitu:

a. Perubahan dalam cita rasa masyarakat b. Perubahan harga dari barang-barang ekspor

c. Kenaikan harga-harga umum (inflasi)

d. Perubahan dalam tingkat bunga dan tingkat pengembalian investasi

e. Perkembangan ekonomi

\section{Produk Domestik Bruto (PDB)}

Untuk meningkatkan pendapatan nasional, pertumbuhan ekonomi, diukur dengan pertumbuhan PDB, dan menjadi salah satu target penting yang harus dicapai dalam pembangunan ekonomi (Tambunan, 2016:45).

Produk Domestik Bruto diartikan sebagai nilai keseluruhan semua barang dan jasa yang diproduksi di dalam wilayah tersebut dalam jangka waktu tertentu (biasanya per tahun). PDB berbeda dari produk nasional bruto karena memasukkan pendapatan faktor produksi dari luar negeri yang bekerja di negara tersebut.

PDB nominal merujuk kepada nilai PDB tanpa memperhatikan pengaruh harga. PDB riil (atau disebut PDB atas dasar harga konstan) mengoreksi angka PDB nominal dengan memasukkan pengaruh dari harga.

$\begin{array}{ccr}\text { PDB dapat dihitung dengan } \\ \text { memakai dua pendekatan, yaitu } \\ \text { pendekatan } & \text { pengeluaran } & \text { dan }\end{array}$ pendekatan pendapatan. Rumus umum untuk PDB dengan pendekatan pengeluaran adalah:

$$
\mathrm{PDB}=\mathrm{C}+\mathrm{I}+\mathrm{G}+(\mathrm{X}-\mathrm{I})
$$

Dimana :

$\mathrm{C}=$ konsumsi adalah pengeluaran yang dilakukan oleh rumah tangga,

$\mathrm{I}=$ investasi oleh sektor usaha,

$\mathrm{G}=$ pengeluaran pemerintah oleh pemerintah

$\mathrm{X}=$ ekspor

$\mathrm{M}=$ impor

Sementara pendekatan pendapatan menghitung pendapatan yang diterima faktor produksi.

$$
\text { PDB = sewa }+ \text { upah }+ \text { bunga }+ \text { laba }
$$

Secara teori, PDB dengan pendekatan pengeluaran dan pendapatan harus menghasilkan angka yang sama. Namun karena dalam praktik menghitung PDB dengan pendekatan pendapatan sulit dilakukan, 
maka yang sering digunakan adalah dengan pendekatan pengeluaran.

Dari data PDB dapat juga diturunkan beberapa indikator ekonomi penting lainnya, seperti :

1. Produk Nasional Bruto, yaitu PDB ditambah dengan pendapatan neto dari luar negeri.

2. Produk Nasional Neto atas dasar harga pasar, yaitu PDB dikurangi dengan seluruh penyusutan atas barang-barang modal tetap yang digunakan dalam proses produksi selama setahun.

3. Produk Nasional Neto atas dasar biaya faktor produksi, yaitu produk nasional neto atas dasar harga pasar dikurangi dengan pajak tidak langsung neto. Pajak tidak langsung neto merupakan pajak tidak langsung yang dipungut pemerintah dikurangi dengan subsidi yang diberikan oleh pemerintah.

4. Angka-angka per kapita, yaitu ukuran-ukuran indikator ekonomi sebagaimana diuraikan di atas dibagi dengan jumlah penduduk pertengahan tahun.

\section{Pengaruh Inflasi, Suku Bunga, dan Nilai Tukar terhadap Produk Domestik Bruto (PDB)}

Produk domestik bruto merupakan salah satu variabel penting dalam ekonomi makro. Di setiap periode sesuatu masyarakat akan menambah kemampuannya untuk memproduksikan barang dan jasa. Ini disebabkan oleh beberapa faktor produksi yang berlaku seperti inflasi, ekspor dan kurs (Verawati, 2010).

Inflasi, ekspor, dan kurs berpengaruh signifikan terhadap produk domestik bruto. Variabel inflasi dan kurs berpengaruh negatif, sedangkan ekspor berpengaruh positif. $\mathrm{Hal}$ ini dijelaskan dalam penelitian Verawati (2010) tentang Pengaruh Inflasi, Ekspor Dan Kurs Terhadap Produk Domestik Bruto Indonesia Tahun 2000-2004.

H1: $P D B$ berhubungan dengan linier negatif dengan inflasi, suku bunga BI, dan nilai tukar Rupiah/US\$
Gambar 1

Kerangka/Konstelasi

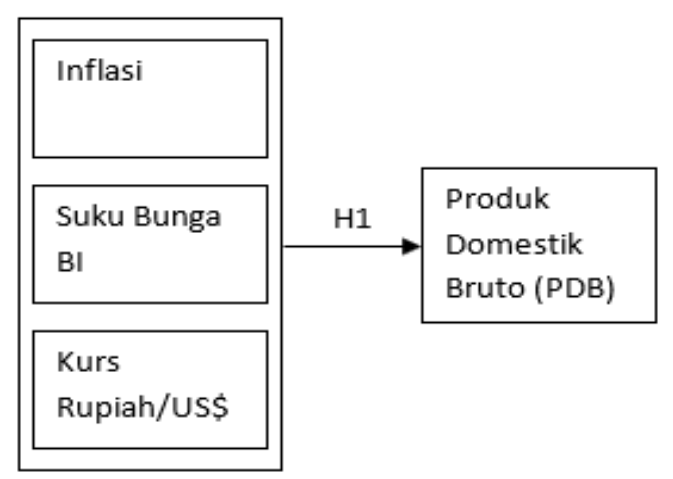

\section{METODE PENELITIAN \\ Sampel Penelitian}

Data dalam penelitian ini adalah data time series tingkat inflasi, suku bunga BI, kurs rupiah, dan produk domestik bruto bulan Nopember 2015 April 2018 (data bulanan) yang bersumber dari Bank Indonesia yang berbentuk jurnal tahun 2015-2018 dan Biro Pusat Statistik yang berbentuk statistik keuangan BI yang diterbitkan Bank Indonesia tahun 2015-2018. Jenis data penelitian ini adalah data sekunder yang berisi informasi tentang PDB, suku bunga BI dan nilai tukar dikumpulkan dari data Bank Indonesia dalam website Bank Indonesia.

Populasi penelitian adalah perekonomian Indonesia dengan salah satu indikatornya yaitu produk domestik bruto bulan Nopember 2015 - April 2018. Sampel penelitian juga adalah produk domestik bruto merupakan salah satu variabel penting dalam ekonomi makro perekonomian Indonesia periode Nopember 2015 - April 2018.

\section{Desain Penelitian}

Penelitian ini merupakan penelitian deskriptif analisis dengan pendekatan kuantitatif, data yang diperoleh dari sampel populasi penelitian dianalisis sesuai dengan metode statistik yang digunakan (software SPSS versi 24) kemudian diinterprestasikan.

$$
\text { Menurut Sugiyono }
$$
penelitian deskriptif adalah penelitian yang dilakukan untuk mengetahui nilai variabel mandiri, baik satu variabel atau 
lebih (independen) tanpa membuat perbandingan, atau menghubungkan dengan variabel yang lain. Menurut Sugiyono (2003:14) penelitian kuantitatif adalah penelitian dengan memperoleh data yang berbentuk angka atau data kualitatif yang diangkakan.

\section{Operasionalisasi Variabel}

Operasionalisasi variabel penelitian dapat dikemukakan sebagai berikut:

Tabel 1

Operasionalisasi Variabel

\begin{tabular}{|c|c|c|c|}
\hline Variabel & Alat ukur & Rumus & Referensi \\
\hline Inflasi & IHK & $\begin{array}{l}\text { IHK }=(\mathrm{Pn} / \mathrm{Po}) \times 100 \\
\text { Di mana, } \mathrm{Pn}=\text { Harga } \\
\text { sekarang } \mathrm{P}=\text { = Harga } \\
\text { pada tahun dasar }\end{array}$ & www.bps,go,ic \\
\hline $\begin{array}{l}\text { Suku bunga } \\
\text { Bank } \\
\text { Indonesia }\end{array}$ & BI Rate & $\begin{array}{l}\text { BI 7-day (Reverse) } \\
\text { Repo Rate }\end{array}$ & www.bi.goid \\
\hline $\begin{array}{l}\text { Kurs } \\
\text { Rupiah/USS }\end{array}$ & Kurs Tengah & 1 dollar $=\ldots . . . R p$ & www.bi.goid \\
\hline $\begin{array}{l}\text { Produk } \\
\text { Domestik } \\
\text { Bruto (PDB) }\end{array}$ & $\begin{array}{l}\text { Penghitungan } \\
\text { Pengeluaran }\end{array}$ & $P D B=C+I+G+(X-M)$ & www.bi.goid \\
\hline
\end{tabular}

\section{Metode Analisis}

Untuk mengetahui korelasi antara hubungan variabel yang akan dianalisis sesuai dengan tujuan penelitian, dengan bantuan program SPSS versi 24 maka digunakan regresi linier berganda:

$\hat{\mathrm{Y}}=\mathrm{a}_{0}+\mathrm{a}_{1} \mathrm{It}+\mathrm{a}_{2} \mathrm{SBt}++\mathrm{a}_{3} \mathrm{NTt}+\mathrm{Ut}$

$\hat{\mathrm{Y}}=\mathrm{PDB}$

It $=$ Inflasi

$\mathrm{SBt}=$ Tingkat Suku Bunga $(\%$ per tahun)

NTt $=$ Nilai Tukar (Rp/ USD)

$\mathrm{a}_{\mathrm{o}}=$ Intersep persamaan regresi

$\mathrm{a}_{1} \mathrm{a}_{2}=$ koefisien regresi

$\mathrm{Ut}=$ kesalahan (penganggu)

Persamaan di atas diestimasi dengan bantuan program SPSS versi 24 untuk periode Nopember 2015 sampai dengan April 2018. Alat statistik yang digunakan dalam analisis, selain regresi adalah ANOVA.

\section{Pengujian Hipotesis}

Untuk menguji pengaruh inflasi, suku bunga BI dan nilai tukar secara bersama-sama terhadap Produk Domestik Bruto (PDB) digunakan Uji-F Anova. Akan diuji apakah koefisien inflasi, suku bunga BI, dan nilai tukar Rupiah/US\$ adalah nol, versus paling tidak ada satu koefisien yang bukan nol, sebagai berikut:

Hipotesa Nol $\left(\mathrm{H}_{\mathrm{o}}\right): \mathrm{a}_{1}=\mathrm{a}_{2}=\mathrm{a}_{3}=0$

PDB tidak berhubungan dengan linier negatif dengan inflasi, suku bunga BI, dan nilai tukar.

Hipotesa Alternatif (Ha): $a_{1} \neq a_{2} \neq a_{3} \neq 0$

PDB berhubungan dengan linier negatif dengan inflasi, suku bunga BI dan nilai tukar rupiah/US\$

Hipotesis nol ditolak apabila $\mathrm{p}$ value (probability value $\leq$ a taraf nyata) terdekat dan terima Hipotesis Alternatif (Gujarati, 1995).

\section{HASIL DAN PEMBAHASAN Uji Multikolonieritas}

Hasil terbesar pada variabel suku bunga BI yang mempunyai korelasi cukup besar dengan variabel PDB, tingkat korelasinya masih di bawah 95\% maka tidak terjadi multikolonieritas.

\section{Uji Homoskedastisitas}

Model regresi yang baik adalah yang homoskedastisitas atau tidak terjadi heteroskedastisitas. Dalam penelitian ini hasilnya yaitu titik-titik menyebar secara acak serta tersebar baik di atas maupun bawah angka 0 pada sumbu Y. Deteksi ada tidaknya gejala heteroskedastisitas tersebut dilakukan dengan melihat ada tidaknya pola tertentu pada grafik scatterplots di bawah ini.

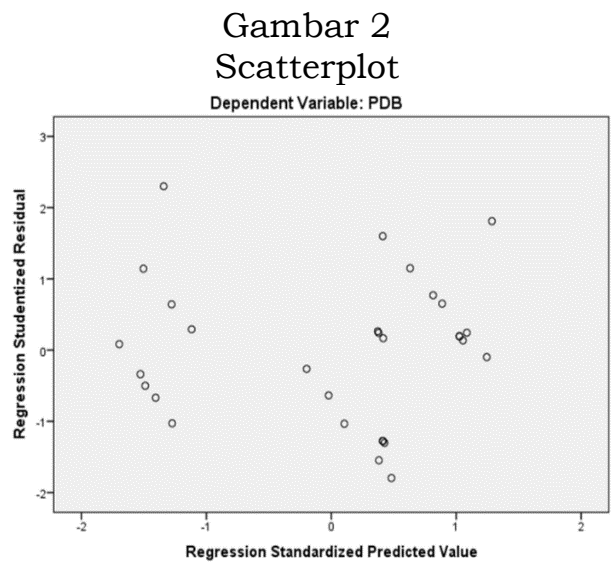


Uji Kelayakan Model

Tabel 2

Model Summary

\begin{tabular}{|l|r|r|r|c|}
\hline Model & \multicolumn{1}{|c|}{$R$} & \multicolumn{1}{|c|}{ R Square } & $\begin{array}{c}\text { Adjusted R } \\
\text { Square }\end{array}$ & $\begin{array}{c}\text { Std. Error of the } \\
\text { Estimate }\end{array}$ \\
\hline 1 & $.905^{3}$ & 0.819 & 0.798 & 98527.624 \\
\hline
\end{tabular}

Dilihat dari tabel tersebut di atas yakni model summary yang menghasilkan nilai $R$ sebesar 0,819 menunjukkan hubungan positif yang sangat kuat antara variabel faktor-faktor Indepanden secara bersama-sama dengan variabel Produk Domestik Bruto (PDB), karena koefisien korelasinya mendekati angka 1 atau $100 \%$. Sedangkan nilai R Square sebesar 0,905 atau $90,5 \%$, hal ini dapat dinyatakan dengan hasil analisa secara bersamasama variabel independen inflasi (X1), suku bunga BI (X2), dan nilai Tukar Rupiah/US\$ (X3) terhadap variabel dependen PDB (Y) memiliki nilai positif dan tingkat persentase pengaruhnya sangat tinggi yaitu sebesar 90,5\% dan sisanya sebesar 9,5\% disebabkan oleh faktor-faktor lain.

\begin{tabular}{|c|c|c|c|c|c|}
\hline \multicolumn{6}{|c|}{$\begin{array}{c}\text { Tabel } 3 \\
\text { ANOVA }^{\mathrm{a}}\end{array}$} \\
\hline Wodel & Sum of Squares & $d f$ & Nean Square & $F$ & Sig. \\
\hline Regression & 1138350398121.760 & 3 & 779450132707.252 & 39.088 & .000 \\
\hline Residual & 252400011657.611 & 26 & 9707692756.062 & & \\
\hline Total & 1390750409779.370 & 29 & & & \\
\hline
\end{tabular}

Berdasarkan pada hasil uji-F dari ANOVA didapat nilai ratio - $\mathrm{F}$ sebesar 39,088 dengan signifikan $F$ sebesar 0,000 karena $0,000<0,05$ (5 persen), maka hipotesis nol (Ho) = PDB tidak berhubungan linier dengan inflasi, suku bunga BI, dan nilai tukar Rupiah/US\$ ditolak. Selanjutnya hipotesis alternatif (Ha) diterima yaitu variabel inflasi (X1), suku bunga $\mathrm{BI}\left(\mathrm{X}_{2}\right)$, dan nilai tukar Rp/US\$ $\left(\mathrm{X}_{3}\right)$ secara bersama-sama berpengaruh sangat signifikan dengan variabel PDB (Y).

\section{Hasil Penelitian}

Dari hasil pengujian korelasi antar variabel dengan menggunakan metode Pearson Correlation, diketahui bahwa:

- Produk Domestik Bruto (PDB) terhadap inflasi korelasi $-0,267$ dengan taraf signifikan $0,000<0,05$ berarti signifikan.

- Produk Domestik Bruto (PDB) terhadap suku bunga BI korelasi sebesar $-0,885$ dengan taraf signifikan $0,000<0,05$ berarti signifikan.

- Produk Domestik Bruto (PDB) terhadap nilai tukar Rp/US\$ korelasi 0.051 dengan taraf signifikan 0,051 > 0,05 berarti tidak signifikan.

- Inflasi terhadap suku bunga BI berkorelasi 0,321 tidak signifikan.

- Nilai tukar rupiah terhadap suku bunga BI berkorelasi 0,151 tidak signifikan.

\section{Pengaruh Inflasi, Nilai Tukar Rupiah/US\$, Suku Bunga BI terhadap Produk Nasional Bruto (PDB)}

Tabel 4

\begin{tabular}{|c|c|c|c|c|c|c|}
\hline \multirow{3}{*}{\multicolumn{2}{|c|}{ Model }} & & Coefficients & & & \\
\hline & & \multicolumn{2}{|c|}{ Unstandardized Coefficients } & \multirow{2}{*}{$\begin{array}{c}\text { Standardized } \\
\text { Coefficients } \\
\text { Beta }\end{array}$} & \multirow[b]{2}{*}{$t$} & \multirow[b]{2}{*}{ Sig. } \\
\hline & & B & Sid. Error & & & \\
\hline \multirow[t]{4}{*}{1} & (Constant) & 1682574.911 & 1111612.356 & & 1.514 & 0.142 \\
\hline & Inflasi & 32798.246 & 3912314.239 & 0.001 & 0.008 & 0.993 \\
\hline & Suku Bunga & .17453111 .753 & 1695566.242 & -0.914 & -10.293 & 0.000 \\
\hline & Kurs & 187.065 & 83.952 & 0.189 & 2.228 & 0.035 \\
\hline
\end{tabular}

Berdasarkan tabel di atas diperoleh dengan nilai signifikan $\mathrm{t} 1=0,993>$ 0,05, maka HO diterima dan H1 ditolak yang berarti bahwa antara variabel inflasi (X1) terhadap variabel PDB (Y) tidak ada pengaruh. Selanjutnya diperoleh dengan nilai signifikan $\mathrm{t} 2=$ $0,000<0,05$, maka $\mathrm{HO}$ ditolak dan $\mathrm{H} 1$ diterima yang berarti bahwa antara variabel suku bunga BI (X2) terhadap variabel $\mathrm{PDB}(\mathrm{Y})$ terdapat pengaruh. Hasil lain diperoleh dengan nilai signifikan $\mathrm{t} 3=0,035<0,05$, maka $\mathrm{HO}$ ditolak dan $\mathrm{H} 1$ diterima yang berarti bahwa antara variabel niali tukar RP/US\$ (X3) terhadap variabel PDB (Y) terdapat pengaruh. 
Dari hasil regresi di atas diketahui persamaan regresi linear bergandanya sebagai berikut:

$\hat{\mathrm{Y}}=1682574,911+32798,246 \mathrm{X} 1-$ $17453111,753 \mathrm{X} 2+187,065 \mathrm{X}_{3}$

Dapat dijelaskan sebagai berikut:

a. Nilai konstanta intersep sebesar 1682574,911 menyatakan bahwa jika tidak terdapat variabel inflasi, suku bunga BI, dan nilai tukar Rp/US\$ maka PDB yang dihasilkan sebesar 1682574,911 atau dapat juga dinyatakan bahwa nilai konstanta intersep sebesar 1682574,911 menggambarkan PDB rata-rata jika inflasinya nilainya nol.

b. Koefisien regresi dari variabel inflasi (X1) sebesar 32798,246 menyatakan bahwa setiap adanya upaya penambahan sebesar satu satuan variabel inflasi, maka akan meningkatkan PDB sebesar 32798,246 dengan anggapan variabel bebas lainnya tetap.

c. Koefisien regresi dari variabel suku bunga BI (X2) sebesar 17453111,753 menyatakan bahwa setiap adanya upaya penambahan sebesar satu satuan variable suku bunga BI, maka akan menurunkan PDB sebesar 17453111,753 dengan anggapan variabel bebas lainnya tetap.

d. Koefisien regresi dari variabel nilai tukar Rp/US\$ (X3) sebesar 187,065 menyatakan bahwa setiap adanya upaya penambahan sebesar satu satuan variable nilai tukar Rp/US\$, maka akan menaikkan PDB sebesar 187,065 dengan anggapan variabel bebas lainnya tetap.

\section{Pembahasan}

Berdasarkan hasil penelitian diperoleh bahwa inflasi, suku bunga BI, dan nilai tukar Rp/US\$ secara bersamasama mempengaruhi Produk Domestik Bruto (PDB) selama periode Nopember 2015 - April 2018. Dengan naiknya inflasi dan suku bunga BI serta terdepresiasinya Rupiah/US\$ maka secara otomatis menurunkan PDB.

Dimulai dari inflasi Bulan Nopember 2015 pada angka 4,89\%, kemudian Bulan Desember tingkat inflasi menurun
3,25\%. Memasuki tahun 2016 diawali dengan tingkat inflasi pada angka 4,14\% dan Bulan Pebruari mencapai angka 4,42\%, selanjutnya di Bulan Maret tingkat inflasi naik menjadi 4,45\%. Kemudian Bulan April tingkat inflasi menurun menjadi 3,60\%, Bulan Mei pun menurun lagi menjadi $3,33 \%$ tetapi Bulan Juni meningkat lagi menjadi $3,45 \%$, dan Bulan Juli menurun lagi tingkat inflasi menjadi 3,21\%.

Awal tahun 2017 tingkat inflasi menaik kembali Bulan Januari 3,49\%, Bulan Pebruari 3,83\%, dan Bulan Maret $3,61 \%$ seterusnya di Bulan April, Mei, Juni tingkat inflasi di angka 4,17\%, 4,33\%, dan 4,37\%. Mulai Bulan Juli, Agustus, September sampai dengan Desember tingkat inflasi terus menurun dimulai dari $3,88 \%, 3,82 \%, \quad 3,72 \%$, $3,58 \%, 3,30 \%$ meningkat sedikit di akhir tahun $3,61 \%$.

Nilai tukar Rupiah/US\$ di akhir tahun 2015 masih tinggi di angka Rp 13.672,- dan Rp 13.854,-. Mengacu data Bloomberg, nilai tukar rupiah pada 1 Januari berada di level 13.830, pada 20 Januari yang ada di level 13.964. Namun memasuki Februari hingga pertengahan Maret, nilai tukar rupiah berangsur-angsur mengalami apresiasi. Pada tanggal $16 \mathrm{Mei}$, rupiah berada di level 13.310. Akan tetapi hanya dalam waktu empat hari saja, kurs melorot menyentuh 13.608 pada 20 Mei. Sejumlah analis menyebut, aksi ambil untung menekan kurs rupiah saat itu. Sehingga, pada akhir bulan Mei mata uang garuda bertengger di level 13.648.

Pada 24 Juni nilai tukar rupiah di pasar spot berada di level 13.391 atau terdepresiasi 1,09 persen dari perdagangan sehari sebelumnya yang berada di level 13.248. Sayangnya, lagilagi terimbas faktor eksternal, sejak 31 Oktober rupiah terus mengalami tekanan, hingga 30 November mencapai 13.555. Pemilihan Presiden Amerika Serikat yang dimenangkan kandidat dari Partai Republik, Donald Trump memberikan efek pelemahan. Bank sentral sendiri tak tinggal diam, yakni dengan melakukan intervensi di pasar valuta asing dan pasar obligasi. Akibatnya, cadangan devisa pun sedikit 
tergerus dari 115 miliar dollar AS pada Oktober, menjadi 111,5 miliar dollar AS pada November. Tetapi menginjak bulan Desember, rupiah kembali terdorong sentimen positif dan menguat hingga per 14 Desember di level 13.294. "Sehingga dari awal tahun sampai 14 Desember rupiah masih menguat sedikit 3,8 persen (Kompas.com, "Menengok Perjalanan Rupiah Sepanjang 2016", Penulis: Estu Suryowati).

Mata uang rupiah sepanjang Januari 2017 bergerak stabil di level Rp 13.300 per USD. Rupiah sempat berada di level 13.281 per USD namun kembali melemah ke level 13.300. Rupiah juga sempat menyentuh level Rp 13.410 per USD, namun kembali menguat ke level Rp 13.371 per USD. Tak berbeda dengan pergerakan di Januari, rupiah masih stabil di level Rp 13.300 per USD. Akhir Februari rupiah berhasil menguat ke Rp 13.338 per USD. Pergerakan rupiah pada Maret juga masih stabil di Rp 13.300 per USD, di akhir bulan rupiah berada di level Rp 13.322 per USD. Rupiah sepanjang April juga stabil di level Rp13.300 per USD. Akhir bulan, rupiah berada di level Rp 13.329 per USD. Rupiah di Mei juga masih parkir di level $\mathrm{Rp} 13.300$ hingga akhir bulan di level Rp 13.323 per USD.

Badan Pusat Statistik (BPS) merilis perkembangan nilai tukar rupiah sepanjang Juni 2017 yang berhasil terapresiasi terhadap dolar AS. Rupiah terapresiasi $0,21 \%$ terhadap dolar AS dengan nilai tukar Rp 13.278,69 per USD. Mata uang rupiah sepanjang Juli 2017 masih berada di level Rp 13.300 per USD. Selama September 2017 dan tercatat rupiah terdepresiasi 0,23\% terhadap dolar Amerika Serikat (AS) menjadi Rp 13.352 per USD. Sepanjang Oktober, rupiah keok melawan dolar AS, bahkan menembus level Rp13.600 per USD.

Pergerakan rupiah sepanjang November berada di level Rp 13.500 per USD. Meski pamor dolar memudar setelah munculnya Bitcoin yang masuk future exchange, namun rupiah hingga bulan di akhir tahun ini berada di Rp 13.546 per USD.
Berdasarkan data kurs referensi Jakarta Interbank Spot Dollar Rate (JISDOR) yang dikeluarkan oleh Bank Indonesia, rupiah sempat ada pada level Rp 13.290 terhadap dollar AS sekaligus sebagai apresiasi yang paling tinggi sejak awal 2018. Bila dicermati, nilai tukar rupiah terhadap dollar AS mulai merangkak di atas Rp 13.500, dari Rp 13.600 hingga Rp 13.700, pada akhir Februari dan awal Maret. Di mana setelah itu sempat turun ke level Rp 13.500 namun bertahap naik ke Rp 13.700 sampai Rp 13.800 pada akhir April (Kompas.com, "Perjalanan Rupiah Sejak Awal Tahun hingga Menembus Level 14.000", Penulis: Andri Donnal Putera).

Bank Indonesia (BI) cukup gencar menurunkan suku bunga acuan selama 2016. Secara total, sudah ada 150 basis point penurunan suku bunga terjadi hingga adanya peralihan ke BI 7 Days Reverse Repo Rate yang sekarang adalah 4,75\%. Rapat Dewan Gubernur (RDG) Bank Indonesia pada 20 dan 22 September 2017 memutuskan untuk menurunkan BI 7-day Reverse Repo Rate sebesar 25 bps dari 4,50\% menjadi $4,25 \%$, dengan suku bunga deposit facility turun 25 bps menjadi $3,50 \%$ dan lending facility turun 25 bps menjadi $5,00 \%$, berlaku efektif sejak 25 September 2017 (www.bi.go.id).

Perekonomian Indonesia tahun 2016 yang diukur berdasarkan Produk Domestik Bruto (PDB) atas dasar harga berlaku mencapai $\mathrm{Rp} 12.406,8$ triliun dan PDB perkapita mencapai Rp 47,96 juta atau US\$3.605. Sementara nilai PDB Atas Dasar Harga Konstan (ADHK) tahun lalu sebesar Rp 9.433 triliun. Nilai PDB ADHB dan ADHK di 2016 tersebut mengalami kenaikan dibanding realisasi dua tahun sebelumnya, yakni di 2015 mencapai Rp 11.531,7 triliun (ADHB) dan Rp 8.982,5 triliun (ADHK), serta Rp 10.569,7 triliun (ADHB), dan Rp 8.564,9 triliun (ADHK) pada 2014.

Perekonomian Indonesia tahun 2017 yang diukur berdasarkan Produk Domestik Bruto (PDB) atas dasar harga berlaku mencapai $\mathrm{Rp} 13.588,8$ triliun dan PDB perkapita mencapai Rp 51,89 juta atau US\$ 3.876,8. Ekonomi 
Indonesia tahun 2017 tumbuh 5,07 persen lebih tinggi dibanding capaian tahun 2016 sebesar 5,03 persen. Dari sisi produksi, pertumbuhan tertinggi dicapai oleh lapangan usaha informasi dan komunikasi sebesar 9,81 persen (www.bps.go.id).

Perekonomian

Indonesia

berdasarkan besaran Produk Domestik Bruto (PDB) atas dasar harga berlaku triwulan I-2018 mencapai Rp 3 505,3 triliun dan atas dasar harga konstan 2010 mencapai $\mathrm{Rp} 2$ 498,4 triliun. Ekonomi Indonesia triwulan I-2018 terhadap triwulan I-2017 tumbuh 5,06 persen (y-on-y) meningkat dibanding capaian triwulan I-2017 sebesar 5,01 persen (www.bps.go.id).

\section{KESIMPULAN}

\section{Simpulan}

- Meningkatnya inflasi, suku bunga BI, dan melemahnya Rupiah/US\$ pada dasarnya diterjemahkan sebagai penurunan PDB berarti melambatnya pertumbuhan ekonomi Indonesia.

- Melemahnya nilai tukar Rupiah/US\$, maka perekonomian Indonesia mengalami capital flight dan beralih berinvestasi pada negara lain. Hal ini tentu merugikan Indonesia sekaligus menurunkan PDB, dimana investasi dari luar kembali ke negaranya masingmasing atau pindah pada negara lain.

\section{Saran}

- Agar tidak terjadi capital flight, Bank Indonesia (BI) harus terus memantau pergerakan nilai tukar Rupiah/US\$ dan menekan Inflasi.

- Mengingat faktor yang mempengaruhi Produk Domestik Bruto (PDB), maka studi lebih lanjut dapat dikembangkan untuk memecahkan beberapa masalah penting yang menggunakan hasil studi ini sebagai landasan.

\section{DAFTAR PUSTAKA}

Sukirno, Sadono. 2003. Pengantar Teori Makroekonomi. Edisi Ketiga. Jakarta: Grafindo.

Sugiyono. 2003. Metode Penelitian Administrasi. Bandung: $\quad \mathrm{CV}$ Alfabeta.

Tambunan, Tulus T. H. 2016. Perekonomian Indonesia Era Orde Lama Hingga Jokowi. Bogor: Penerbit Ghalia Indonesia.

Verawati, Tri Norma. 2010. Pengaruh Inflasi, Ekspor, dan Kurs terhadap Produk Domestik Bruto Indonesia Tahun 2000-2004. Research Gate. https://www.researchgate.net/pub lication/50951712_PENGARUH_IN FLASI_EKSPOR_DAN_KURS_TERH ADAP_PRODUK_DOMESTIK_BRUT O INDONESIA TAHUN 20002004

https://www.bloomberg.com. $\quad 7 \quad$ Mei 2018.

http://money.cnn.com, 31 Maret 2015.

https://www.indonesiainvestments.com.7 Mei 2018

www.bi.go.id.

www.bps.go.id.

www.kompas.com. 